\author{
RAFAEL CONFETTI GATSIOS \\ Master's Degree in Controllership and Accounting from the College of Economics, Business Administration \\ and Accounting of Ribeirão Preto at the Universidade de São Paulo (FEA-USP). \\ Professor at the Accounting Department from the Centro Universitário da Fundação Educacional de Barretos (Unifeb). \\ Avenida dos Bandeirantes, 3.900, Ribeirão Preto - SP - Brasil - CEP 14040-900 \\ E-mail: rafaelgatsios@fearp.usp.br
}

\title{
JOSÉ MARCOS DA SILVA
}

Master's Degree in Controllership and Accounting from the College of Economics, Business Administration and Accounting of Ribeirão Preto at Universidade de São Paulo (FEA-USP).

Professor at the Accounting Department from the Universidade Estácio. Avenida dos Bandeirantes, 3.900, Ribeirão Preto - SP - Brasil - CEP 14040-900

E-mail: josemarcos@usp.br

\section{MARCELO AUGUSTO AMBROZINI}

Doctor in Business Administration from the College of Economics, Business Administration and Accounting of Ribeirão Preto at the Universidade de São Paulo (FEA-USP).

Professor from the College of Economics, Business Administration and Accounting of Ribeirão Preto at the Universidade de São Paulo. Avenida dos Bandeirantes, 3.900, Ribeirão Preto - SP - Brasil - CEP 14040-900 E-mail: marceloambrozini@yahoo.com.br

\section{ALEXANDRE ASSAF NETO}

Doctor in Business Administration (Finance) from the College of Economics, Business Administration and Accounting of Ribeirão Preto at the Universidade de São Paulo (FEA-USP).

Director of Instituto Assaf.

Rua Madre Cabrini, 341, São Paulo - SP - CEP 04020-001

E-mail: alexandreassafneto@gmail.com

\section{FABIANO GUASTI LIMA}

Doctor in Business Administration from the College of Economics, Business Administration and Accounting of Ribeirão Preto at the Universidade de São Paulo (FEA-USP). Professor from the College of Economics, Business Administration and Accounting of Ribeirão Preto at the Universidade de São Paulo. Avenida dos Bandeirantes, 3.900, Ribeirão Preto - SP - Brasil - CEP 14040-900

E-mail: fgl@usp.br

Este artigo pode ser copiado, distribuído, exibido, transmitido ou adaptado desde que citados, de forma clara e explícita, o nome da revista, a edição, o ano e as páginas nas quais o artigo foi publicado originalmente, mas sem sugerir que a RAM endosse a reutilização do artigo. Esse termo de licenciamento deve ser explicitado para os casos de reutilização ou distribuição para terceiros. Não é permitido o uso para fins comerciais. 


\section{ABSTRACT}

Purpose: This study aims to assess the impact of adopting IFRS standard on the equity cost of Brazilian open capital companies in the period of 2004-2013. Originality/gap/relevance/implications: The adoption of International Financial Reporting Standards aims to increase the quality of accounting information. Studies performed in Europe suggest that, after the adoption of the IFRS standard, there was a reduction in the equity cost of companies due to the reduction of information asymmetry and risk.

Key methodological aspects: The equity cost was calculated using the capital asset pricing model (CAPM) adapted to the Brazilian case. The empirical strategy was the difference analysis in differences, comparing the results of companies that voluntarily adopted the IFRS with companies that adopted IFRS after the mandatory adoption period.

Summary of key results: The results indicate that the adoption of the IFRS standard does not contribute to reduce the equity cost in Brazil.

Key considerations/conclusions: Suggesting that the process of adopting the international accounting standard may take more time to impact the equity cost of Brazilian open capital companies, since the impact of IFRS is not related only with the adoption, but also with its use by companies and users.

\section{KEYWORDS}

Cost of equity. CAPM. IFRS. Quality of accounting information. Brazil.

\section{INTRODUCTION}

The IFRS is a set of accounting standards issued by the International Accounting Standards Board (IASB), aiming to create a unique high quality model of 
international accounting standards for information users. The standards proposed by this committee present a greater and greater coverage. Nowadays, more than I20 countries use the international accounting standards for disclosing the content of accounting information (Deloitte, 20I2).

According to Ball (2006), the adoption of the IFRS, over individual standards, presents traits of greater reliability for investors, given to the fact that the standards of the IFRS are of easy understanding by international analysts and investors, enabling the reduction of information asymmetry.

In Brazil, the change for the new accounting standards was carried out in two stages: partial adoption from January 2008 on and, after January 2010 , the mandatory international standards adoption for open capital companies in Brazil. The study of Santos and Calixto (2010) indicates improvement in the quality of accounting information in the Brazilian capital market after the adoption of international accounting standards.

Recent studies in other countries show that the adoption of international standards has reached the aim of improvement in information quality, as demonstrated by Barth, Landsman and Lang (2008) and Jiao, Koning, Mertens and Roosenboom (20II). Within the research line of accounting information quality improvement, studies assess the impact of the adoption of international standards on equity cost of companies, because, according to the paper of Lee, Walker and Christensen (20I0), the international standards would be related to the increase of informational content disclosed by companies and the prevalence of essence over form tends to reduce the information asymmetry and the consequent reduction of shareholder risk.

The study of Li (20IO) points that the adoption of the IFRS in Europe has reduced the equity cost of companies listed in the capital market. The studies of Daske, Hail, Leuz and Verdi (2008) indicate that the reduction of capital cost can be explained by the institutional differences between the countries. However, Gao (20IO) points out that the IFRS adoption and the improvement of informational content cannot lead to the reduction of equity cost, since the new disclosures of information can alter the investment assessment by the shareholders.

For the Brazilian case, the results may not follow the ones found for the European case for different reasons: I. the adoption of international standards took place in a period of impact of the 2008 international financial crisis; 2. greater difference between the former Brazilian accounting standards and the IFRS; 3. influence of tax accounting in drafting accounting reports; 4. capital market less developed, and 5 . institutions with lower enforcement power.

The papers in this research line are still recent in Brazil. Nardi and Silva (20I4) point out a small reduction on equity cost of Brazilian companies after 
the adoption of international accounting standards, but with the results of papers being influenced by the impact of the 2008 international financial crisis and concerning only to the IBRX-Ioo companies in the period of mandatory IFRS adoption period in Brazil.

Due to what was said and, aiming to contribute to elucidate the effects of the IFRS adoption on equity cost in Brazil, the research problem of this paper is presented: Does the IFRS adoption contributes for the reduction of equity cost of open capital companies in Brazil?

Thus, when answering the research problem presented, this work has as main purpose to assess whether the IFRS adoption has reduced the equity cost of open capital companies in Brazil.

The data used in this work were obtained from the Economatica ${ }^{\circledR}$, Damodaran On line platform and the financial reports disclosed by the companies in the sample. The data were collected for the period from 2004 to 2013 and divided in three parts: I. prior to the IFRS adoption, before 2008; 2. period of partial, not mandatory adoption, 2008 and 2009; and 3. period of mandatory adoption, from 2010 to 2013.

The equity cost of companies was calculated by the model capital asset pricing (CAPM) presented by (Sharpe, I964) and adapted to the Brazilian case, as presented by Assaf Neto, Lima and Araujo (2008). For analyzing the impact of the IFRS adoption on equity cost of companies, the methodology of panel data and differences in differences were used. In order to control the impact of other factors on the cost of equity cost, the dummy variables of profitability, indebtedness, voluntary disclosure, basic interest rate of Brazil, national capital return and capital market volatility index were used.

The results of this paper indicate that contrary to the findings in the studies for European countries, the IFRS adoption has still not contributed significantly for the reduction of equity cost of open capital companies in Brazil.

Nonetheless, the paper presents the importance of the use of economic variables in the models of IFRS impact assessment in the equity cost of Brazilian companies since the 2008 financial crisis affected significantly the profitability of fixed and variable income market in Brazil and in the world.

Besides this introductory part, this paper presents a literature review on the IFRS adoption, accounting information quality, and the impact of the IFRS adoption on the equity cost of companies.

Following, there is the presentation of the research methodology and the results found and, finally, the final considerations and benchmarks used in the research are presented. 


\section{THEORETICAL FRAME}

\subsection{IFRS ADOPTION, ACCOUNTING INFORMATION QUALITY AND EQUITY COST}

The IFRS is a set of international accounting standards aiming the improvement of information quality and the standardization of accounting statements in the world (Deloitte, 20I2).

According to Iudícibus and Lopes (2008), the main change the adoption of international standards has brought for the informational set was the preference of the essence over the form, which enables the record of economic transaction of the operations by the company.

According to Ball (2006), the IFRS adoption, over the individual standards, presents traits of greater reliability for investors, since the IFRS is of easy understanding among international analysts and investors, enabling the reduction of information asymmetry.

The IFRS adoption presents specific traits in the different countries which have already concluded the convergence to international standards, as the countries still in the period of IFRS adoption.

In Europe, the convergence process to international standards was carried out earlier. In 2002, there was the announcement of the IFRS adoption which forced the European companies with shares traded in the stock market to disclose their accounting information in the new international standards from 2005 and on (Deloitte, 20I2).

Just like Europe, Australia carried out a rapid action of international accounting standards adoption. In the beginning of 2005, Australian companies began disclosing the information according to the IFRS. According to Cotter, Tarca and Wee (20I2), the local standards of Australia had great adhesion to international standards, making the adoption process easier.

The convergence to international standards in China, according to Ding and $\mathrm{Su}$ (2008), followed the slow process of Chinese opening economy. Thus, the authors believe that Chinese companies and the local government are still not prepared for the IFRS adoption. Also, the transition process continues slowly in the United States. The Securities Exchange Commission (SEC) announced the proposal of convergence to the international accounting standards in 20I0; however, the adoption should be carried out from 2015 and on (Deloitte, 20I2).

In Brazil, the convergence process to the international standards started in 2005 with the determination of Conselho Federal de Contabilidade (CFC) and Comitê de Pronunciamentos Contábeis (CPC), aiming to unify the process deci- 
sions of the IFRS adoption. Moreover, in the same period, Bolsa de Valores, Mercadorias e Futuros de São Paulo - BM\&F Bovespa made the accounting information disclosure mandatory for companies of level 2 corporate governance. In 2006, Banco Central do Brasil (BCB) determined that the financial institutions disclosed the information according to the IFRS from 2010 and on.

After this period of initial preparation, the IFRS adoption was carried out in two phases in Brazil: I. approval of Law n. II.638/07, allowing the partial adoption from 2008 and on, and 2. the mandatory adoption from 2010 and on to Brazilian open capital companies (Lima, 20II).

After the adoption of the international accounting standards, several studies were carried out to assess the impact of such adoption on the capital market. Aiming to check whether the IFRS adoption had changed the accounting information, Barth et al. (2008) studied the information disclosed by companies in different countries before and after the convergence to the international accounting standards. The authors found evidences of improvement in the informational content after the IFRS adoption.

According to Lee et al. (2010), the adoption of the international accounting standards increases the quality of information disclosed, thus reducing the information asymmetry and, consequently, the costs for analysis and decision-making by investors, reflecting directly in the reduction of capital cost of companies.

Glaum, Baetge, Grothe and Oberdörster's (2013) paper assesses the impact of the IFRS adoption in Germany on the accuracy of analysts' forecasts from I997 to 2005 . The results indicated a significant increase in analysts' accuracy after the international accounting adoption, suggesting that greater information disclosure affects the quality of forecast performed.

The study of Daske et al. (2008) assesses the market value and liquidity of companies of 26 countries, totaling 3,I00 observations, after the IFRS adoption. The results found pointed out a significant increase in market liquidity of companies in the sample, in the share turnover and in the market value of companies analyzed, since the reduction of equity cost is related to institutional aspects.

On the other hand, $\mathrm{Li}$ (2010) analyzed a sample of 6,456 data of European companies to assess the impact of international accounting adoption on the equity cost of open capital companies. The study found evidences of 47 -base-point reduction in the capital cost of companies from 1996 to 2005 . Nonetheless, the studies indicated that the reduction in capital cost is related to the enforcement for applying the standards.

Nevertheless, it is important to point out that the IFRS adoption may have a contrary effect on accounting information quality as presented in the study of Barth et al. (2008) which can lead to the increase in the capital cost of companies 
due to the possibility of greater discretion of information disclosed. As presented by Gao (2010), the adoption of the international accounting standards can increase the equity cost of companies, since it alters the informational content assessed by investors. Nonetheless, as highlighted by La Porta, Lopez de Silanes and Shleifer (1998), the institutional aspects are important for the final result on accounting information quality and equity cost.

It is important to point out that, according to Soderstrom and Sun (2007), the impact of the adoption of international standards in accounting information quality is related to the institutional aspects of adopting countries. Among these characteristics, the development of capital market and the enforcement for the execution of such standards are highlighted. However, the study of Markov and Tamayo (2006) reveals that the effect of the IFRS adoption may require a learning period both for companies and information users.

Therefore, the effects of the IFRS adoption in Brazil may be different from those found in studies carried out for the European case, due to institutional and economic differences between Europe and Brazil, as well as the fact that the international accounting standards have been recently adopted in Brazil and the strong impact of the 2008 financial crisis.

In Brazil, the paper of Nardi and Silva (20I4) analyzed the impact of the IFRS on capital cost of open capital companies only in the period of mandatory adoption of the IFRS. The studies used the companies from the IBRX-Ioo index and the Differences in Differences methodology (DD), being the capital cost calculation based on Li's (20IO) methodology and without the use of control variables for the macroeconomic alterations of the period, besides assessing the effects only in the period after the mandatory IFRS adoption for companies of the IBXRX-Ioo. The results indicated a small 7-base point reduction for capital cost in the period.

This paper aims to expand the assessment of the impact of partial and mandatory IFRS adoption on equity cost in Brazil since the results found indicate a low relation between the IFRS adoption and equity cost of Brazilian open capital companies. Therefore, this paper proposes to assess the equity cost by the CAPM adapted to the Brazilian reality, since this model works with the ex post variables and thus, does not depend on market analysts' future expectations for its assessment. Nonetheless, the use of CAPM is highlighted due to its wide use in the Brazilian capital market.

Finally, this paper aims to contribute to the assessment of the impact of economic variables on the equity of open capital companies in Brazil in the period of IFRS adoption because it was in this period that great volatility of fixed income and variable income markets took place in Brazil and in the world due to the effects of the 2008 financial crisis. 
After presenting the theoretical frame and based on evidences presented, the following research hypothesis was elaborated and it will be investigated through the methodology proposed in Section 3.

- Ho: The adoption of international accounting standards decreased the equity cost of Brazilian open capital companies.

\section{METHODOLOGY}

This paper used data of Economatica ${ }^{\circledR}$, Damodaran On line platform and financial reports disclosed by the companies in the sample.

The period of analysis is from 2004 to 2013 with companies listed at the BMF\&F-Bovespa, with exception of companies of the financial sector. The decision for excluding the data of financial companies was because of the difference in accounting standards and the specific regulation for this sector. For the data analysis and the construction of models, the STATA ${ }^{\circledR}$ statistics program was used. The definition of the analysis period is justified when comprehending the period prior to the IFRS adoption, partial or mandatory adoption. Nonetheless, the choice for the beginning of the series in 2004 aimed to reduce the impact of the effects of the Brazilian presidential election in the variables used in the paper.

The variable used to estimate the equity cost of companies was built through the CAPM, presented by Sharpe (I964) and adapted to the Brazilian reality. According to Assaf Neto et al. (2008), the use of CAPM in Brazil show the need of adaptation because, due to the volatility of the national capital market and the high Brazilian basic interest rate, the model loses validity for the calculation of the premium by the market risk and the calculation of beta company. Thus, the same authors suggest a model adapted to the Brazilian reality.

In equation (I) the model used in this research for the calculation of equity cost of Brazilian open capital companies is presented. This paper uses the methodology presented by Assaf Neto et al. (2008), and the CAPM was adapted for the Brazilian case.

The choice for the use of CAPM is due to the fact it is widely used in calculating equity cost in processes of opening and closing of capital of Brazilian open capital companies, bringing the methodology used close to the Brazilian reality. It is important to highlight that the use of CAPM is justified despite all the limitations, since, as presented by Assaf Neto et al. (2008), CAPM continues being the most used model in the calculation of equity cost. This statement is also 
endorsed by the studies of Graham and Harvey (2002) and Copeland, Koller and Murrin (2002).

Even so, other methodologies of equity cost calculation use the market analysts' forecast ( $\mathrm{Li}, 20 \mathrm{IO})$. Thus, its mediation is impacted by the predictive ability of analysts. In Brazil, according to Martinez (2007), the market analysts' forecasts show positive bias, that is, the estimates of earnings carried out by market analysts are greater than the results disclosed by the companies. Therefore, the calculation of equity cost through this methodology could suffer an impact from the bias of market analysts' forecast.

$$
\begin{gathered}
K e=R f(E U A)+\beta(R m(E U A)-(R f(E U A))-\text { American Inflation } \\
+ \text { Brazilian Inflation }+ \text { Brazil's country risk }
\end{gathered}
$$

Ke Brasil $_{j}=$ equity cost for the Brazilian market

$R f=$ USA risk-free rate

$\beta=$ beta coefficient of Brazilian companies

$R m=$ USA market return rate

$(R m-R f)=$ difference between market return and risk-free return.

American Inflation = inflation forecasted for the next $\mathrm{I} 2$ months in the USA

Brazilian Inflation = inflation forecasted for the next $\mathrm{I} 2$ months in Brazil

Brazil Risk = Brazilian country risk

The risk-free rate $(R f)$ was calculated by the annual average of returns generated by the American government bonds, the Treasury Bills (T-bill) of 20-year maturity. The market return was calculated by the return average of the last 20 years of the Dow Jones share index.

The values of the beta $(\beta)$ coefficient of companies of the sample were calculated following the methodology presented by Assaf Neto et al. (2008) and Assaf Neto (2007), having as basis, the unleveraged beta of American companies of the same economic sector and leveraged by the level of indebtedness of companies in the sample, onerous liabilities (Net income tax) divided by the market value. The unleveraged betas of USA companies were obtained at Damodaran On line.

The American inflation was calculated by the mean of the CPI forecasted for the next 12 months. The Brazilian inflation was measured by the mean IPCFIPE forecasted for the next I2 months. The Brazil risk used was the mean of the average of the $E M B I+B R$ of the period, according to J.P. Morgan's methodology.

The sample was divided in three periods: I. prior to the IFRS adoption, from 2004 to $2007 ; 2$. period of partial non-mandatory adoption, from 2008 to 2009 ; and 3. period of mandatory adoption, after 2010. The division of the sample 
was carried out by mean of the dummy variables which represent each of the moments mentioned: PRIOR, PART and COMPL.

In the paper, the panel data methodology with fixed and random effects was used. Panel data refers to the observation of different units in different moments of time (Wooldridge, 2008). The general model for this methodology is represented by Equation (2).

$$
Y_{j, t}=\beta_{\circ}+\beta_{\mathrm{I}} x_{\mathrm{I} j, t}+\beta_{n} x_{k j, t}+e_{j, t}
$$

In Equation (2), the subscript $i$ represents the different individuals and the subscript $t$ denoted the time period analyzed. $Y_{i, t}$ represents the dependent variable, $\beta_{\text {oi,t }}$ refers to the intercept value, $\beta_{k}$ the angular coefficient of the $k$ covariate of the model and $e_{i, t}$ the forecast error.

According to Wooldridge (2008), the panel data models are used because they present a possibility of working with a greater number of data, combining cross-section and time series analysis methodologies, with a greater number of freedom level and efficiency of estimators.

In this paper, the differences in differences (DD) methodology was used due to the fact that, through the panel data analysis and despite the controls used, it is possible that omitted variables influence the relation between the interest variable and the dependent variable.

For this analysis, the company sample was divided into two groups: the control group, formed by companies that adopted the IFRS before the mandatory adoption of the international accounting standards in Brazil, due to the fact they disclosed information in other accounting standards, and the companies that adopted the IFRS in a mandatory way, after the adoption of international accounting standards in Brazil (OBR).

According to Wooldridge (2008), the model is defined by a control group A and a treatment group $\mathrm{B}, \mathrm{dB}$ is the dummy that takes value I for the treatment group and $\circ$ for the control group, and $\mathrm{d} 2$ is the dummy that represents the period of the study. Thus, the model is presented in Equation (3).

$$
Y_{j, t}=\Omega_{\circ}+\Omega_{\mathrm{I}} \mathrm{d} 2_{j, t}+\Omega_{2} d B_{j, t}+\Omega_{3} d 2 \times d B_{j, t}+e_{j, t}
$$

In Equation (4), the $\Omega_{3}$ coefficient represents the interest value since it captures the joint effects of the period and the control group, thus, allowing to assess the difference between the control and treatment groups in the period of interest. The $Y_{t}$ variable represents the independent variable, the $\Omega_{o}$ coefficient shows the individual effect of the period, and the $\beta_{\mathrm{I}}$ coefficient indicates the isolated effect 
of the difference between the groups. Finally, the $\beta_{\circ}$ coefficient represents the constant of the model and $e_{i t}$ represents the error of the model.

This methodology was used in Nardi and Silva's (20I4) paper. However, this paper includes control variables for the economic scenario and risk, besides using the CAPM for the calculation of equity cost and measuring the effect of the IFRS adoption in Brazil. Thus, the DD model for this study in presented in Equation (4).

$$
\begin{aligned}
& K e_{j, t}=\beta_{\circ}+\beta_{\mathrm{I}} P A R C_{j, t}+\beta_{2} C O M P L_{j, t}+\beta_{3} O B R_{j, t}+\beta_{4} P A R C_{j, t} \\
& \quad \times O B R_{j, t}+\beta_{5} C O M P L_{j, t} \times O B R_{j, t}+\beta_{k} \operatorname{CONTROLE~}_{j, t}+\mu_{j, t}
\end{aligned}
$$

In Equation (4), the $\beta_{\mathrm{I}}$ and $\beta_{2}$ coefficients reflects the relationships between equity cost and the periods prior to the adoption, partial adoption and after the IFRS adoption, $\beta_{k}$ represents the impact of the control variables on analysts' accuracy, $\mu_{j, t}$ represents the random error of $j$ company in the $t$ period, $\phi_{\circ}$ represents the difference between the voluntary and mandatory adopting groups and the $\beta_{4}$ and $\beta_{5}$ coefficients indicates the cross impact between the adoption periods and the companies that adopted the IFRS mandatorily, being these the variables of interest of the model.

Following the studies of Daske et al. (2008), Li (2010) and Nardi and Silva (20I4), control variables were used in the model aiming to mitigate the institutional and market effects on the equity cost of companies. The variables used are presented next:

- $\quad$ LNATIVO - Represents the natural logarithm of total assets of $j$ company calculated in the $t$ period;

- DIVPL - Variable that represents the gross debt on the NE of $j$ company in the $t$ period;

- $\quad R O E$ - Return on Equity (annual) for $j$ company in the $t$ period;

- $\quad L N I B O V$ - Natural logarithm of IBOVESPA in the $t$ period;

- $\quad$ RISCOBRASIL - EMBI+BR, according to the J.P. Morgan methodology in the $t$ period;

- $\quad$ LNSELIC - Average of SELIC rate in the period;

- $\quad$ LNVIX - Average of VIX ${ }^{\circledR}$, "fear index", calculated by the Chicago Board Options Exchange (CBOE), the volatility index implied of sales option of the S\&P 500 index in the period;

- $\quad O B R-D u m m y$ variable that takes value equal to I in case $j$ company has adopted the IFRS after 2010 and $\mathrm{O}$ in case it had disclosed the accounting information in standards different from the BR-GAAP before 2010. 
Nevertheless, the dummy variables of the sector were included in the model to control the effect of activity difference on equity cost. The corporate governance variables were not included in the model due to their high multicollinearity with the $O B R$ variable since companies that disclosed information in other accounting standards have a greater level of corporate governance.

After the presentation of the theoretical frame of the research, the results of the paper will be presented in the part that follows. In this part, the descriptive statistics of variables used in the models and the results found for the assessment model of the impact of the international accounting standards adoption on the equity cost of Brazilian open capital companies are presented.

\section{RESULTS}

This research sample is composed by open capital companies listed at the BM\&F-BOVESPA, other than financial institutions, along the period from 2004 to 2013 , with data available in the period. Data of companies that did not present values for different variables along the period analyzed were excluded. Companies from the financial sector were excluded due to the difference of the standards of information disclosed by those companies, as well as the difference in regulation of these companies in the Brazilian market. Table I shows the total sample and the subsamples of this paper. In the period, the data of I85 companies of the Brazilian capital market, divided in branch of industry according to the Economatica ${ }^{\circledR}$ ranking, were analyzed.

\section{TABLE I}

STUDY SAMPLE

\begin{tabular}{c|c|ccc|cc}
\hline & SAMPLE & \multicolumn{3}{|c|}{ PERIOD } & \multicolumn{2}{c}{ ADOPTION PROFILE } \\
\hline & TOTAL - DATA & PRIOR & PARTIAL & COMPLETE & MANDATORY & VOLUNTARY \\
\hline DATA & 1325 & 471 & 341 & 513 & 963 & 362 \\
\hline
\end{tabular}

Source: Elaborated by the authors.

Aiming to assess the capital cost more completely, the descriptive statistics of variables used for the Ke calculation by CAPM is presented. In Table 2, the average values, standard deviation, minimum and maximum of capital cost variables, $(K e)$, risk free $(R f)$, companies beta $(\beta)$, market return $(R m)$, USA inflation, Brazil inflation and Brazil risk are presented. 
In Table 2, it is seen that the equity cost of Brazilian open capital companies increased in the period of partial IFRS adoption when compared to the period prior to the adoption, going from $10.38 \%$ to $14.6 \mathrm{I} \%$. Nevertheless, in the period of mandatory adoption, the equity cost falls when compared to the period of partial adoption, but it continues above what was evinced in the period prior to the IFRS adoption in Brazil, with a value of $12.23 \%$.

\section{TABLE 2}

CAPITAL COST DESCRIPTIVE STATISTICS

\begin{tabular}{|c|c|c|c|c|c|}
\hline VARIABLE & OBS & AVERAGE & $\begin{array}{l}\text { STANDARD } \\
\text { DEVIATION }\end{array}$ & MIN. & MAX. \\
\hline \multicolumn{6}{|c|}{ TOTAL PERIOD - 2004-2013 } \\
\hline $\mathrm{Ke}$ & 1325 & $12.18 \%$ & $3.91 \%$ & $6.41 \%$ & $52.44 \%$ \\
\hline BETA & 1325 & 0.75 & 0.60 & 0.01 & 6.15 \\
\hline Rf & 1325 & $3.29 \%$ & $1.00 \%$ & $1.78 \%$ & $4.71 \%$ \\
\hline $\mathrm{Rm}$ & 1325 & $8.39 \%$ & $15.55 \%$ & $6.65 \%$ & $10.93 \%$ \\
\hline USA inflation & 1325 & $2.36 \%$ & $1.27 \%$ & $-0.35 \%$ & $3.83 \%$ \\
\hline Brazil inflation & 1325 & $4.95 \%$ & $1.26 \%$ & $2.53 \%$ & $6.56 \%$ \\
\hline Brazil risk & 1325 & $2.66 \%$ & $1.00 \%$ & $1.81 \%$ & $5.42 \%$ \\
\hline \multicolumn{6}{|c|}{ PRIOR PERIOD - 2004-2007 } \\
\hline $\mathrm{Ke}$ & 471 & $10.38 \%$ & $5.22 \%$ & $6.41 \%$ & $52.44 \%$ \\
\hline BETA & 471 & 0.25 & 0.48 & 0.01 & 6.15 \\
\hline $\mathrm{Rf}$ & 471 & $4.32 \%$ & $0.25 \%$ & $4.04 \%$ & $4.71 \%$ \\
\hline $\mathrm{Rm}$ & 471 & $10.05 \%$ & $0.62 \%$ & $9.41 \%$ & $10.93 \%$ \\
\hline USA inflation & 471 & $3.03 \%$ & $0.27 \%$ & $2.67 \%$ & $3.39 \%$ \\
\hline Brazil inflation & 471 & $4.38 \%$ & $1.35 \%$ & $2.53 \%$ & $6.56 \%$ \\
\hline Brazil risk & 471 & $3.15 \%$ & $1.38 \%$ & $1.81 \%$ & $5.42 \%$ \\
\hline
\end{tabular}


TABLE 2 (CONCLUSION)

CAPITAL COST DESCRIPTIVE STATISTICS

\begin{tabular}{|c|c|c|c|c|c|}
\hline VARIABLE & OBS & AVERAGE & $\begin{array}{l}\text { STANDARD } \\
\text { DEVIATION }\end{array}$ & MIN. & MAX. \\
\hline \multicolumn{6}{|c|}{ PARTIAL ADOPTION PERIOD - 2008-2009 } \\
\hline $\mathrm{Ke}$ & 341 & $14.61 \%$ & $2.41 \%$ & $9.37 \%$ & $29.61 \%$ \\
\hline BETA & 341 & 1.07 & 0.56 & 0.24 & 5.95 \\
\hline Rf & 341 & $3.04 \%$ & $0.80 \%$ & $2.25 \%$ & $3.85 \%$ \\
\hline $\mathrm{Rm}$ & 341 & $8.30 \%$ & $1.31 \%$ & $6.98 \%$ & $9.61 \%$ \\
\hline USA inflation & 341 & $1.74 \%$ & $2.10 \%$ & $-0.03 \%$ & $3.83 \%$ \\
\hline Brazil inflation & 341 & $4.91 \%$ & $1.25 \%$ & $3.65 \%$ & $6.16 \%$ \\
\hline Brazil risk & 341 & $3.03 \%$ & $0.02 \%$ & $3.01 \%$ & $3.06 \%$ \\
\hline \multicolumn{6}{|c|}{ MANDATORY ADOPTION PERIOD - 2010-2013 } \\
\hline $\mathrm{Ke}$ & 513 & $12.23 \%$ & $1.97 \%$ & $7.97 \%$ & $21.45 \%$ \\
\hline BETA & 513 & 0.99 & 0.38 & 0.12 & 2.97 \\
\hline Rf & 513 & $2.51 \%$ & $0.68 \%$ & $1.78 \%$ & $3.30 \%$ \\
\hline $\mathrm{Rm}$ & 513 & $6.94 \%$ & $0.31 \%$ & $6.65 \%$ & $7.40 \%$ \\
\hline USA inflation & 513 & $2.15 \%$ & $0.68 \%$ & $1.46 \%$ & $3.15 \%$ \\
\hline Brazil inflation & 513 & $5.49 \%$ & $0.88 \%$ & $3.87 \%$ & $6.39 \%$ \\
\hline Brazil risk & 513 & $1.96 \%$ & $0.07 \%$ & $1.84 \%$ & $2.05 \%$ \\
\hline
\end{tabular}

Source: Elaborated by the authors.

Through the results, an increase of beta variable (which measures the risk of investing in a company) was seen. It is important to observe that the risk free fell significantly during the period analyzed, as well as the market risk.

Both results are due to the effect of the 2008 international financial crisis because, as a strategy of reduction of the crisis effect, the U.S. Central Bank opted to reduce the interest rate in the period. Nevertheless, the reduction of market return is due to the effect of the crisis in the capital market. Finally, in Table 3, there is the presentation of data showing that the control variables have also gone through changes along the analysis periods. 
TABLE 3

INDEPENDENT VARIABLES DESCRIPTIVE STATISTICS

\begin{tabular}{|c|c|c|c|c|c|}
\hline VARIABLE & OBS & AVERAGE & $\begin{array}{l}\text { STANDARD } \\
\text { DEVIATION }\end{array}$ & MIN & MAX \\
\hline \multicolumn{6}{|c|}{ TOTAL PERIOD 2004-2013 } \\
\hline LNATIVO & 1325 & 14.88 & 1.71 & 4.26 & 20.44 \\
\hline$R O E-\%$ & 1325 & 22.21 & 29.59 & 0.00 & 362.00 \\
\hline DIVPL & 1325 & 26.44 & 16.64 & 0.00 & 88.10 \\
\hline LNIBOV & 1325 & 10.83 & .3029 & 10.17 & 11.14 \\
\hline LNSELIC & 1325 & 2.48 & .2506 & 2.11 & 2.95 \\
\hline LNVIX & 1325 & 3.01 & .3360 & 2.54 & 3.48 \\
\hline \multicolumn{6}{|c|}{ PRIOR PERIOD 2004-2007 } \\
\hline LNATIVO & 471 & 14.48 & 1.77 & 4.26 & 19.52 \\
\hline$R O E-\%$ & 471 & 23.55 & 31.18 & 0.00 & 291.60 \\
\hline DIVPL & 471 & 24.09 & 15.97 & 0.00 & 88.10 \\
\hline$\angle N I B O V$ & 471 & 10.64 & .3363 & 10.17 & 11.06 \\
\hline LNSELIC & 471 & 2.74 & .1842 & 2.48 & 2.95 \\
\hline LNVIX & 471 & 2.68 & .1402 & 2.54 & 2.86 \\
\hline \multicolumn{6}{|c|}{ PARTIAL PERIOD 2008-2009 } \\
\hline LNATIVO & 341 & 1.81 & 1.54 & 11.14 & 20.27 \\
\hline$R O E-\%$ & 341 & 24.02 & 37.20 & 0.00 & 362.00 \\
\hline DIVPL & 341 & 26.56 & 17.52 & 0.00 & 77.80 \\
\hline LNIBOV & 341 & 10.83 & .3016 & 10.53 & 11.13 \\
\hline LNSELIC & 341 & 2.41 & .1032 & 2.31 & 2.52 \\
\hline LNVIX & 341 & 3.46 & .01894 & 3.44 & 3.48 \\
\hline
\end{tabular}


TABLE 3 (CONCLUSION)

INDEPENDENT VARIABLES DESCRIPTIVE STATISTICS

\begin{tabular}{lccccc}
\hline \multicolumn{1}{c}{ VARIABLE } & OBS & AVERAGE & $\begin{array}{c}\text { STANDARD } \\
\text { DEVIATION }\end{array}$ & MIN & MAX \\
\hline LNATIVO & 513 & 15.29 & 1.66 & 10.33 & 20.44 \\
\hline ROE - \% & 513 & 19.79 & 21.04 & 0.10 & 180.20 \\
\hline DIVPL & 513 & 28.53 & 16.40 & 0.00 & 79.50 \\
\hline LNIBOV & 513 & 11.00 & .1076 & 10.84 & 11.14 \\
\hline LNSELIC & 513 & 2.28 & .1355 & 2.11 & 2.46 \\
\hline LNVIX & 513 & 3.00 & .1968 & 2.65 & 3.18 \\
\hline
\end{tabular}

Source: Elaborated by the authors.

Therefore, part of the behavior of capital cost in Brazil can be explained by the impact of the 2008 international financial crisis on the variables used to calculate the beta of companies or in the control variables. No direct relation with the IFRS adoption in Brazil was observed. Thus, it is clear that there is the need of using economic variables to mitigate the 2008 international financial crisis effects on the assessment of impact of the IFRS adoption on the equity cost of open capital companies in Brazil. With emphasis, it is seen the fall of ROE of companies in the period of mandatory IFRS adoption in Brazil, the return volatility of IBovespa and the reduction of Selic. Finally, the rise of indebtedness of companies in the sample in the period of mandatory IFRS adoption in Brazil is seen.

Through the data analysis of Table 3 , it is noticed that the financial variables of companies change along the period analyzed. Therefore, part of the effect that would be attributed to the IFRS adoption is due to the financial changes of companies. Nonetheless, the IBovespa behavior variation is seen in the period, besides the Brazil risk behavior, which had already been demonstrated.

The panel data and Differences in Differences methodology were used to isolate the effect of the IFRS adoption on the equity cost of Brazilian open capital companies. Therefore, in Table 4, the results of panel data for both the periods of partial and mandatory adoption are presented.

The model was constructed by using the methodology of random robust effects to heteroscedasticity. Even so, the dummy variables were used to control 
the difference between company sectors of the sample in order to mitigate the effect of differences in equity cost between the sectors of companies in the sample. The difference in sectors supports the choice of the random effect methodology, as well as the Hausman test.

\section{TABLE 4}

MODEL - EQUITY COST AND IFRS IN BRAZIL

\begin{tabular}{llll}
\hline \multicolumn{1}{r}{ VARIABLES } & COEFICIENTS & STANDARD DEVIATION & P-VALUE \\
\hline KE & & & \\
\hline PARCIAL & -0.041604 & 0.0055233 & 0 \\
\hline COMPLETA & -0.0134509 & 0.0031579 & 0 \\
\hline OBRPARCIAL & -0.0020595 & 0.0031944 & 0.519 \\
\hline OBRCOMPLETA & -0.0016349 & $\mathbf{0 . 0 0 2 2 1 2 7}$ & 0.46 \\
\hline OBR & $\mathbf{0 . 0 0 0 4 8 0 9}$ & $\mathbf{0 . 0 0 1 5 5 7}$ & 0.757 \\
\hline LNATIVO & -0.0013679 & $\mathbf{0 . 0 0 0 5 6 9 9}$ & 0.016 \\
\hline ROE & -0.0000221 & 0.0000217 & 0.307 \\
\hline DIVPL & $\mathbf{0 . 0 0 0 2 3 7}$ & $\mathbf{0 . 0 0 0 0 6 0 4}$ & 0 \\
\hline LNIBOV & -0.1047378 & $\mathbf{0 . 0 0 5 8 7 9 9}$ & 0 \\
\hline LNVIX & $\mathbf{0 . 0 9 9 1 5 1 4}$ & $\mathbf{0 . 0 0 5 2 6 0 2}$ & 0 \\
\hline LNSELIC & -0.086137 & $\mathbf{0 . 0 0 5 6 0 8 9}$ & 0 \\
\hline CONSTANTE & $\mathbf{1 . 2 1 5 4 3 9}$ & $\mathbf{0 . 0 6 8 6 7 6 1}$ & 0 \\
\hline
\end{tabular}

Adjusted R2 - 51.70\%

Robust model to heteroscedasticity

Control by sectors

Model - random effect

Source: Elaborated by the authors.

When observing the results found, it is seen that the PARCIAL and COMPLETA variables present negative and statistically significant coefficients at a $1 \%$ level, indicating that, during the period of partial adoption and mandatory IFRS adoption in Brazil, there was a reduction of the equity cost of open com- 
panies. Nevertheless, this reduction of capital cost cannot be directly associated to the adoption of international accounting standards in Brazil; for this reason, the interest variables are OBRPARCIAL and OBRPARCIAL, since they compare the behavior of equity cost of companies that adopted the IFRS voluntarily and mandatorily. The coefficients are negative, but they do not present statistical significance at a Io\% level. Thus, it is not possible to indicate that the IFRS has changed the equity cost of open capital companies in Brazil.

Nonetheless, it is important to highlight the statistic significance of LNATIVO, DIVPL, LNIBO, LNVIX and LNSELIC, indicating that the financial and economic aspects are essential in determining the equity cost in Brazil.

Therefore, it is suggested that these variables be used to mitigate effects of the omission of significant variables in the model as, in case these variables are omitted, the effect will be incorporated by the other explanatory variables, that is, part of the effect that results from economic variables can be misinterpreted as IFRS impact.

The other variables used in the model do not present statistic significance at the maximum level of ı०\%. Therefore, the coefficients found do not indicate any relation between the IFRS adoption and these control variables.

Finally, it is highlighted that the separation by sectors was significant in the result analysis.

The results of this research are contrary to the hypothesis of reduction of equity cost of companies after the adoption of the international accounting standards presented in the studies of Daske et al. (2008) and Li (2010) for Europe. Nonetheless, through the results found, evidences that the IFRS adoption did not have impact on the quality of accounting information disclosed to the market are presented.

Concerning the studies for the Brazilian case, the difference of results found in the study of Nardi and Silva (20I4) can be granted to the inclusion of control variables for the behavior of the basic interest rate in Brazil and the fluctuations of the capital market as, in this period, these variables suffered a strong variation due to the 2008 international financial crisis, as highlighted in the study of Lima (20II). The analysis divided by period of partial adoption and period of mandatory adoption, the use of CAPM for the calculation of equity costs of companies and the inclusion of economic variables to control the effects of the 2008 financial crisis are highlighted.

The absence of the IFRS impact on the equity cost of Brazilian companies can be explained by the institutional fragility in Brazil and the low enforcement power for the correct implementation of the international accounting standards, as suggested in the studies of La Porta et al. (1998) and Soderstrom and Sun (2007). 
The great influence of tax accounting and the low development level of the Brazilian capital market should also be mentioned. Nonetheless, the effects may appear more clearly as time goes by, as Markov and Tamayo (2006) suggest the need of some adaptation time for companies and shareholders and the effective improvement of the informational content.

These results indicate the need of greater attention to the adoption of the international accounting standards in Brazil because they indicate, to the regulatory agencies, that just the change of disclosure standards does not change the quality of the informational content. Even so, the results can point to fragilities in the Brazilian capital market, suggesting that the companies do not have incentive for the increase of the information disclosed to the market. The high control concentration in the Brazilian capital market stands out, thus reducing the incentive to better quality information disclosure for the minority shareholders.

The results are important for capital market investors because the decision of resource allocation is directly related to the investor's equity cost. For the investors, this result is important because it presents evidence of low impact of the IFRS adoption on the quality of information disclosed to the market, not contributing, therefore, to the reduction of informational asymmetry in the Brazilian capital market.

\section{FINAL CONSIDERATIONS}

This paper sought to assess the effect of the international accounting standards - IFRS - on accounting information quality in Brazil. Specifically, this research analyzed whether there was reduction of equity cost of open capital companies after the IFRS adoption in Brazil. The study was carried out for the period from 2004 to 2013 with companies of the Brazilian capital market. The sample was composed by 1325 observations with data obtained in the Economatica ${ }^{\circledR}$ platform, Damodaran On line and financial reports disclosed by the companies in the sample. The methodologies used in this paper were the panel data analysis, associated with differences in differences model. Both were used aiming to isolate the effect of the IFRS on the equity cost of companies.

The estimate of equity cost of companies was obtained following the CAPM by Sharpe (1964) and adapted to suit the Brazilian reality. The sample was divided in three periods: prior to the IFRS adoption in Brazil; period of partial adoption and period of mandatory IFRS adoption. Nonetheless, there was an additional division between the companies that adopted the IFRS voluntarily and 
the ones that adopted the international accounting standards mandatorily. The choice of the CAPM adapted to the Brazilian reality is due to its wide use in assessment of opening and closing of capital of open capital companies in Brazil, besides the fact it is a methodology that does not depend on future estimates of market analysts.

To isolate the internal effects of companies and the economic effects on the equity cost of companies along the period analyzed, control variables, such as company size, profitability on net equity, mandatory or voluntary adoption of the IFRS, IBovespa, VIX and Selic in the period were used.

The results of this paper indicate there was no reduction of the equity cost of companies in the periods of partial and mandatory IFRS adoption in Brazil. These results are contrary to the hypothesis proposed in the paper and different studies of Daske et al. (2008), Li (2010) and Nardi and Silva (20I4) and they did not present evidence of improvement in the informational content of companies and the consequent reduction of the equity cost of open capital companies. The significant result of the financial and economic control variables stands out, thus indicating the need of control to assess the impact of the IFRS adoption on the equity cost of open capital companies in Brazil.

The difference of the results found in the study of Nardi and Silva (2014) can be granted to the difference of equity cost calculation, besides the inclusion of control variables for the behavior of the basic interest rate in Brazil and the capital market fluctuations because, during this period, these variables suffered strong variation due to the 2008 international financial crisis, as pointed out in Lima's (20II) study. Nonetheless, the inclusion of the period of partial adoption in the model is highlighted, separating the effects of the complete adoption and the period of partial adoption.

This result is contrary to the evidences found by the studies carried out for the European case, and it can be explained by the fragility of Brazilian institutions and the low enforcement power for the execution of new accounting standards, as suggested in the studies of La Porta et al. (1998), Markov and Tamayo (2006), Soderstrom and Sun (2007) and Gao (2010). Finally, the great importance of tax accounting and the low development of the capital market in Brazil can be pointed out as factors that justify the results found in this paper.

These results suggest the need of greater attention to the international standards adoption in Brazil since they indicate to the regulatory agencies that just the change of disclosure standards does not change the quality of informational content. The paper presents limitations due to the sample and statistical methods used, besides the fact that the results reflect the analysis period. Thus, 
it is suggested that future studies be carried out with a longer period of analysis and with statistical methods that allow a more accurate interpretation of the effects analyzed.

\section{IMPACTO DA ADOÇÃO DO PADRÃO IFRS NO CUSTO DE CAPITAL PRÓPRIO DAS EMPRESAS DE CAPITAL ABERTO NO BRASIL}

\section{RESUMO}

Objetivo: Este trabalho se propõe a avaliar o impacto da adoção do padrão IFRS sobre o custo de capital próprio das empresas de capital aberto no Brasil.

Originalidade/lacuna/relevância/implicações: A adoção do padrão international financial reporting standards (IFRS) apresenta como objetivo o aumento da qualidade das informações contábeis. Estudos realizados para a Europa indicam que, após a adoção do padrão IFRS, verificou-se a redução do custo de capital próprio das empresas devido à redução da assimetria de informação e do risco.

Principais aspectos metodológicos: O estudo foi realizado no período de 2004 a 20I3. O custo de capital próprio foi calculado por meio do capital asset pricing model (CAPM) adaptado ao caso brasileiro. A metodologia utilizada foi a de análise de diferenças em diferenças, comparando os resultados de empresas que adotaram voluntariamente o padrão IFRS com empresas que adotaram o padrão IFRS após o período de adoção obrigatória.

Síntese dos principais resultados: Os resultados indicam que a adoção do padrão IFRS não contribui para a redução do custo de capital próprio no Brasil.

Principais considerações/conclusões: Sugerindo assim que o processo de adoção do padrão internacional de contabilidade pode levar um maior tempo para impactar o custo de capital próprio das empresas brasileiras de capital aberto, uma vez que o impacto do padrão IFRS não está relacionado apenas com a adoção da norma, mas também com seu uso pelas empresas e usuários.

\section{PALAVRAS-CHAVE}

Custo de capital próprio. CAPM. Adoção do padrão IFRS. Qualidade da informação contábil. Brasil. 


\section{IMPACTO DE ADOPTAR LA NIIF SOBRE EL COSTO DE CAPITAL DE LAS EMPRESAS QUE FIGURAN EN BRASIL}

\section{RESUMEN}

Objetivo: Este estudio tiene como objetivo evaluar el impacto de adoptar la NIIF sobre el costo de capital de las empresas que figuran en Brasil. El estudio se realizó entre 2004 y 2013.

Originalidad/laguna/relevancia/implicaciones: La adopción de las normas internacionales de información financiera (NIIF) tiene el objetivo de mejorar la calidad de la información contable. Los estudios realizados en Europa muestran que después de la adopción de la norma NIIF fue encontrado una reducción del costo del capital de las empresas debido a la reducción de la asimetría de la información y el riesgo.

Principales aspectos metodológicos: El costo de capital se calculó utilizando el capital asset pricing model (CAPM) adaptado para el caso brasileño. La metodología utilizada fue el análisis de las diferencias en diferencias, comparando los resultados de las compañías que adoptaron voluntariamente la NIIF con las empresas que adoptaron la NIIF después del período de adopción obligatoria.

Síntesis de los principales resultados: Los resultados indican que la adopción de la norma NIIF no contribuye a reducir el costo del capital en Brasil.

Principales consideraciones/conclusiones: Lo que sugiere que el proceso de adopción de la norma internacional de información financiera puede tomar un tiempo más largo para impactar el costo del capital de las empresas brasileñas negociados, ya que el impacto de la norma NIIF no se relaciona únicamente con la adopción de la norma, sino también su uso por las empresas y los usuarios.

\section{PALABRAS CLAVE}

Costo de capital. CAPM. Adopción de las normas NIIF. Calidad de la información contable. Brasil.

\section{REFERENCES}

Assaf Neto, A., Lima, F. G., \& Araujo, A. M. (2008). Uma proposta metodológica para o cálculo do custo de capital no Brasil. Revista de Administração, 32(I), 72-83.

Ball, R. (2006). International Financial Reporting Standards (IFRS): pros and cons for investors. Accounting and Business Research, 36(Special issue), 5-27. 
Assaf Neto, A. (2007). Finanças Corporativas e Valor. São Paulo: Atlas.

Barth, M., Landsman, W. R., \& Lang, M. H. (2008). International accounting standards and accounting quality. Journal of Accounting Research, 46(3), 467-498.

Cotter, J., Tarca, A., \& Wee, M. (20I2). IFRS adoption and analysts' earnings forecasts: Australian evidence. Accounting and Finance, 52(2), 395-4I9.

Copeland, T., Koller, T., \& Murrin, J. (2002). Avaliação de empresas - valuation: calculando e gerenciando o valor das empresas (3a ed.). São Paulo: Makron Books.

Daske, H., Hail, L., Leuz, C., \& Verdi, S. R. (2008). Mandatory IFRS reporting around the world: early evidence on the economic consequences. Journal of Accounting Research, 46(I2), I085-II42.

Deloitte. (20I2). IFRS ao seu alcance 2012: um guia para o aperfeiçoamento dos conceitos do padrão contábil global. Retrieved August 20, 20I4, from http://www.iasplus.com/en/publications/brazil/ other/...20I2/at.../Pocket_IFRS-20I2.pdf.pdf.

Ding, Y., \& Su, X. (2008). Implementation of IFRS in a regulated market. Journal Accounting Public Policy, 27(6), 474-479.

Gao, P. (2010). Disclosure quality, cost of capital, and investor welfare. The Accounting Review, 85(I), I-29.

Glaum, M., Baetge, J., Grothe, A., \& Oberdörster, T. (2013). Introduction of International Accounting Standards, disclosure quality accuracy of analysts' earnings forecasts. European Accounting Review, 22(I), 79-II6.

Graham, J. R., \& Harvey, C. R. (2002). How do CFOs make capital budgeting and capital structure decisions. Journal of Applied Corporate Finance, 15(I), 8-23.

Hausman, J. A. (I978). Specification tests in econometrics. Econometrica, 46(6), I25I-I27I.

Iudícibus, S., \& Lopes, A. (2008). Teoria Avançada da Contabilidade. São Paulo: Atlas.

Jiao, T., Koning, M., Mertens, G., \& Roosenboom, P. (20II). Mandatory IFRS adoption and its impact on analysts' forecasts. International Review of Financial Analysis, 21(I), 56-63.

La Porta, R., Lopez de Silanes, F., \& Shleifer, A. L. (I998). Law and Finance. Journal of Political Economy, 106(6), III3-II55.

Lee, E., Walker, M., \& Christensen, H. B. (20I0). Mandating IFRS: its impact on the cost of equity capital in Europe. Journal of International Accounting Research, 9(I), I43-I68.

Li, S. (2010). Does mandatory adoption of International Financial Reporting Standards in the European Union reduce the cost of equity capital?. The Accounting Review, 85(2), 607-636.

Lima, J. B. (20II). A relevância da informação contábil e o processo de convergência para as normas IFRS no Brasil. Tese de doutorado, Universidade de São Paulo, São Paulo, SP, Brasil.

Markov, S., \& Tamayo, A. (2006). Predictability in financial analyst forecast errors: learning or irrationality? Journal of Accounting Research, 44(4), 725-76I.

Martinez, A. L. (2007). Determinantes da acurácia das previsões dos analistas do mercado de capitais. Revista UnB Contábil, 10(2), 69-96.

Nardi, P. C., \& Silva, L. R. (2OI4). A adoção completa das IFRS no Brasil reduz o custo de capital próprio? Anais da Associação Nacional dos Programas de Pós-Graduação em Ciências Contábeis (ANPCONT). ANPCONT, 2014. São Paulo (SP). Retrieved September 26, 20I4, from http://congressos.anpcont.org.br/congressos-antigos/viii/images/343-39c94.pdf?20I50429II44I7.

Santos, E. S., \& Calixto, L. (20I0). Impactos do início da harmonização contábil internacional (Lei Iı.638/07) nos resultados de empresas abertas. ERA - Eletrônica, 9(I). Retrieved October 28, 2013, from http://www.scielo.br/pdf/raeel/vgni/vgnia6.pdf. 
Sharpe, W. (1964). Capital assets price: a theory of market equilibrium under conditions of risk. Journal of Finance, 19(3), 425-442.

Soderstrom, N. S., \& Sun, K. J. (2007). IFRS Adoption and Accounting Quality: A Review. European Accounting Review, 16(4), 675-702.

Wooldridge, J. M. (2008). Introdução à econometria: uma abordagem moderna. São Paulo: Cengage Learning. 